\title{
Effects of recombinant human lactoferrin on calcium signaling and functional responses of human neutrophils
}

\author{
Daria V. Grigorieva ${ }^{a}$, Irina V. Gorudko, ${ }^{a}$, Ekaterina V. Shamova ${ }^{a}$, Maria S. Terekhova ${ }^{a}$, \\ Elena V. Maliushkova ${ }^{\mathrm{b}}$, Igor V. Semak ${ }^{\mathrm{b}}$, Sergey N. Cherenkevich ${ }^{\mathrm{a}}$, Alexey V. Sokolov ${ }^{\mathrm{c}, \mathrm{d}, \mathrm{e}, \mathrm{f}}$, \\ Alexander V. Timoshenko ${ }^{g}$ \\ ${ }^{a}$ Department of Biophysics, Faculty of Physics, Belarusian State University, Minsk, 220030, Belarus \\ ${ }^{\mathrm{b}}$ Department of Biochemistry, Faculty of Biology, Belarusian State University, Minsk, 220030, Belarus \\ ${ }^{\mathrm{c}}$ Laboratory of Biochemical Genetics, Department of Molecular Genetics, Institute of Experimental Medicine, St. Petersburg, 197376, Russia \\ ${ }^{\mathrm{d}}$ Department of Fundamental Problems of Medicine and Medical Technology, Faculty of Dental Medicine and Medical Technologies, Saint-Petersburg State University, St. \\ Petersburg, Russia, 199034 \\ ${ }^{\mathrm{e}}$ Department of Biophysics, Federal Research and Clinical Center of Physical-Chemical Medicine, Moscow, 119435, Russia \\ ${ }^{\mathrm{f}}$ Department of Biochemical Research, Centre of Preclinical Translational Research, Almazov National Medical Research Centre, St. Petersburg, 197341, Russia \\ ${ }^{g}$ Department of Biology, The University of Western Ontario, London, ON, N6A 5B7, Canada
}

\section{A R T I C L E I N F O}

\section{Keywords:}

Recombinant human lactoferrin

Neutrophils

Calcium ions

Degranulation

Cell aggregation

Respiratory burst

\begin{abstract}
A B S T R A C T
Lactoferrin is a non-heme iron-binding glycoprotein with multiple health-beneficial functions including antimicrobial, antioxidant, anticarcinogenic, and immunomodulatory effects. There is emerging evidence that neutrophils may serve as targets of lactoferrin in vivo, and here we show how recombinant human lactoferrin (rhLf) can contribute to this regulation. Indeed, our results demonstrate that rhLf binds efficiently to human neutrophils and induces a variety of early cellular responses such as mobilization of intracellular $\mathrm{Ca}^{2+}$, remodeling of actin cytoskeleton, and degranulation (release of lysozyme and myeloperoxidase). In addition, rhLf facilitates lectin-induced $\mathrm{H}_{2} \mathrm{O}_{2}$ production and stabilization of lectin-induced cellular aggregates. The role of calcium signaling seems to be essential for rhLf-induced activation of neutrophils, as $\mathrm{Ca}^{2+}$-chelators inhibit degranulation response while lectin-induced $\mathrm{H}_{2} \mathrm{O}_{2}$ production correlates significantly with cytoplasmic $\mathrm{Ca}^{2+}$ elevation. Taken together, our findings justify that rhLf can activate neutrophil functions in a calcium-dependent manner and hence, can potentiate innate immune responses.
\end{abstract}

\section{Introduction}

Lactoferrin (Lf) is a cationic iron-binding glycoprotein $(M \sim 78 \mathrm{kDa})$ of the transferrin family, which is found at high concentration in exocrine fluids (e.g. breast milk) and specific granules of neutrophils $(\sim 15$ $\mu \mathrm{g} / 10^{6}$ neutrophils) $[1,2]$. Although the homeostatic concentration of Lf in blood is relatively low $(0.2-0.6 \mu \mathrm{g} / \mathrm{ml})$, it increases under inflammation conditions up to $200 \mu \mathrm{g} / \mathrm{ml}$ due to secretion from activated neutrophils [3-5]. As such, Lf is a multifunctional protein, which is not only involved in regulation of iron homeostasis but also has many health-beneficial functions including antimicrobial, antioxidant, anticarcinogenic, and immunomodulatory effects $[1,2,6-8]$. These functions depend on Lf binding to specific receptors on the surface of many effector cells (neutrophils, monocytes, macrophages, lymphocytes, epithelial and endothelial cells) and the subsequent transmembrane signaling $[9,10]$.

Neutrophils are the major class of white blood cells that play a key role in innate immune responses and, among other functions, can both secrete and bind Lf [11-14]. Earlier findings demonstrated that neutrophils exposed to human Lf (from colostrums) exhibited an increase in

\footnotetext{
Abbreviations: Lf, lactoferrin; rhLf, recombinant human lactoferrin; EDTA, ethylenedinitrilotetraacetatic acid; HRP, horseradish peroxidase; fMLP, N-formyl-Met-

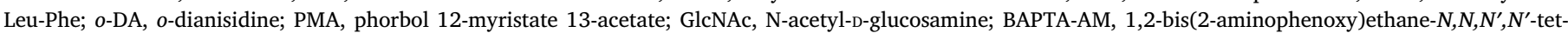

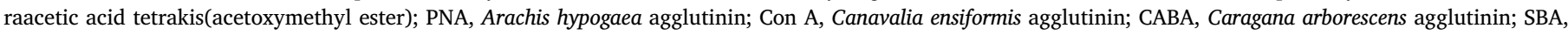

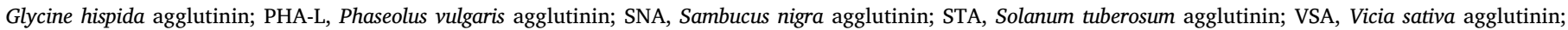

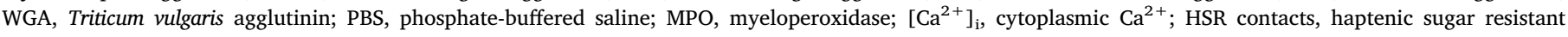
contacts; ROS, reactive oxygen species

* Corresponding author. Department of Biophysics, Faculty of Physics, Belarusian State University, Minsk, 220030, Belarus.

E-mail address: irinagorudko@gmail.com (I.V. Gorudko).
} 
random motility and were primed to produce more superoxide anion radicals [15]. Iron-unsaturated human Lf was noticed to inhibit spontaneous apoptosis of human neutrophils at the earliest events of this process $[3,16]$. Moreover, it was found that Lf secreted from specific neutrophil granules is localized to the plasma membrane of neutrophils and markedly suppressed NETs release [17]. In addition, purified bovine Lf was reported to enhance the phagocytic activity of human neutrophils [18], while human Lf promoted neutrophil adherence to endothelial cells [19].

Health-beneficial properties of Lf promote clinical trials of this protein and large-scale production using recombinant technologies due to limitations of natural sources of Lf in bovine or human milk $[1,2,6]$. As the biological activity of recombinant proteins should be validated before their application, this study was conducted to investigate the properties of new recombinant human Lf (rhLf) obtained from milk of transgenic goats, bred as a part of the national scientific program in Belarus. Biochemical characterization of the rhLf was thoroughly conducted and showed high similarity/identity to Lf from human milk [20]. Here, we report that rhLf from transgenic goats binds efficiently with human neutrophils and activates or facilitates, in a calcium-dependent manner, several early responses of neutrophils (degranulation, respiratory burst, and cell-cell adhesion), which are essential for innate immunity.

\section{Materials and methods}

\subsection{Reagents}

Cytochalasin B, DAPI, ethylenedinitrilotetraacetatic acid (EDTA), Fluoromount $^{\mathrm{TM}}$ aqueous mounting medium, genistein, HEPES, Histopaque-1077, horseradish peroxidase (HRP), ( \pm )-methoxyverapamil, Micrococcus lysodeikticus, $\mathrm{NaN}_{3}$, N-formyl-Met-Leu-Phe (fMLP), $\mathrm{NiCl}_{2}$, o-dianisidine (o-DA), phorbol 12-myristate 13-acetate (PMA), poly-L-lysine, polymyxin B, scopoletin, triton X-100, trypan blue, U73122, and wortmannin were purchased from Sigma-Aldrich (St. Louis, MO, USA). N-acetyl-D-glucosamine (GlcNAc) was from Roth (Karlsruhe, Germany). Chitin hydrolysate was from Vector Laboratories (Burlingame, CA, USA). Alexa Fluor 488 phalloidin, fura-2AM, and 1,2bis(2-aminophenoxy)ethane- $N, N, N^{\prime}, N^{\prime}$-tetraacetic acid tetrakis(acetoxymethyl ester) (BAPTA-AM) were purchased from Molecular Probes (Leiden, Netherlands). All plant lectins were obtained from Lectinotest (Lviv, Ukraine) and included agglutinins from Arachis hypogaea (PNA), Canavalia ensiformis (Con A), Caragana arborescens (CABA), Glycine hispida (SBA), Phaseolus vulgaris (PHA-L), Sambucus nigra (SNA), Solanum tuberosum (STA), Vicia sativa (VSA), and Triticum vulgaris (WGA).

\subsection{Isolation of recombinant human lactoferrin}

Milk of transgenic goats was used to isolate rhLf as described previously $[20,21]$. Briefly, milk was centrifuged at $20,000 \mathrm{xg}$ for $30 \mathrm{~min}$ at $4{ }^{\circ} \mathrm{C}$ to remove the fat and then was acidified to $\mathrm{pH} 4.6$ by adding $1 \mathrm{M}$ $\mathrm{HCl}$ at $37^{\circ} \mathrm{C}$ for $30 \mathrm{~min}$ to precipitate casein. The precipitate was removed by centrifugation $(20,000 \mathrm{xg}$ for $30 \mathrm{~min})$, the $\mathrm{pH}$ of the supernatant was adjusted to 7.0 by adding $1 \mathrm{M} \mathrm{NaOH}$, and the second step of centrifugation was performed to collect final rhLf-enriched supernatant. The supernatant was loaded onto a TOYOPEARL SP-550 cation exchange column ("Tosoh Bioscience", Griesheim, Germany), which was equilibrated and washed with a buffer containing $20 \mathrm{mM}$ sodium phosphate, $0.4 \mathrm{M} \mathrm{NaCl}, \mathrm{pH} 7.0$. A linear gradient of $0.4-1.0 \mathrm{M} \mathrm{NaCl}$ was used to elute cationic proteins and the fractions with rhLf were pooled, and after diafiltration concentrated by ultrafiltration using Sartorius Vivaflow-200 crossflow cassette with $30 \mathrm{kDa}$ MWCO membrane, and lyophilized. The purity of rhLf was verified by sodium dodecyl sulfate polyacrylamide gel electrophoresis, which showed a single band of $\sim 80 \mathrm{kDa}$. The percentage of rhLf purity was not less than $99 \%$, iron saturation - not more than $10 \%$ [21].

Lf eluted from TOYOPEARL SP-550 column was subjected to an additional cation exchange chromatography on Mono $S$ column ("Amersham Pharmacia Biotech", Uppsala, Sweden) to separate rhLf from goat Lf. The concentration of rhLf in the milk of transgenic goats ranged from $2 \mathrm{~g} / 1$ to $16 \mathrm{~g} / \mathrm{l}$, which exceeded significantly the concentration of native goat Lf in the milk of various goat breeds $(0.073-0.089 \mathrm{~g} / \mathrm{l})$ [22].

\subsection{Determination of endotoxin content in rhLf sample}

The endotoxin content in rhLf samples was controlled using a LAL (Limulus amebocyte lysate) Chromogenic Endpoint Assay kit from HyCult Biotech (Uden, The Netherlands) according to the manufacturer's instructions. Serial dilutions of LPS from Escherichia coli (150, 50, $17,6,2,0 \mathrm{pg} / \mathrm{ml}$ ) were used as calibration standards. All tested samples of rLf, which were used in this study, showed the bacterial endotoxin content less than $17 \mathrm{pg}$ per $10 \mu \mathrm{g}$ of the protein.

\subsection{FITC labeling of rhLf}

A sample of rhLf $(10 \mu \mathrm{M}$ in $0.1 \mathrm{M}$ Na-carbonate buffer, $\mathrm{pH}$ 9.0) was mixed with few drops of FITC ( $40 \mu \mathrm{M}$ in DMSO) to have a molar ratio of 1:4 (rhLf:FITC) and kept on ice for $2 \mathrm{~h}$. The reaction mix was dialyzed twice against 100-fold excess of phosphate-buffered saline (PBS, $\mathrm{pH}$ 7.4, $10 \mathrm{mM} \mathrm{Na} 2 \mathrm{HPO}_{4} / \mathrm{KH}_{2} \mathrm{PO}_{4}, 137 \mathrm{mM} \mathrm{NaCl}, 2.7 \mathrm{mM} \mathrm{KCl}$ ) for $12 \mathrm{~h}$ and used for flow cytometry experiments to study rhLf binding with human neutrophils [23].

\subsection{Isolation of human neutrophils}

Venous blood samples were obtained from healthy donors at the Republican Scientific and Practical Center of Transfusiology and Medical Biotechnologies (Minsk, Belarus). The blood was collected in tubes containing $3.8 \%(\mathrm{w} / \mathrm{v})$ trisodium citrate as anticoagulant at a ratio of 9:1. Neutrophils were isolated at room temperature by centrifugation in a Histopaque-1077 density gradient as described elsewhere [24]. Cells were resuspended and stored in a cold $\left(4{ }^{\circ} \mathrm{C}\right) \mathrm{PBS}$, containing $11 \mathrm{mM}$ D-glucose. The cell viability was not less than $95 \%$ as per trypan blue exclusion test and $95 \%$ of the cell population were neutrophils as per the segmented morphology of cell nuclei stained with DAPI.

\subsection{Analysis of rhLf binding to human neutrophils}

Binding of rhLf to surface of neutrophils was assessed by flow cytometry using reagents and equipment from Beckman Coulter (Brea, California, USA). Briefly, a sample of whole blood (100 $\mu$ l) was incubated with FITC-labeled rhLf $(250 \mu \mathrm{g} / \mathrm{ml})$ for $10 \mathrm{~min}$ and with CD45PC5 antibody for $15 \mathrm{~min}$ at ambient temperature. Next, erythrocytes were lysed with $1 \mathrm{ml}$ of VersaLyse lysing solution for $10 \mathrm{~min}$ and the resulting cell suspension was analyzed using the Navios flow cytometer. The subpopulation of human neutrophils was selected based on CD45PC5 fluorescence intensity in combination with lateral light scattering.

\subsection{Measurement of $\mathrm{H}_{2} \mathrm{O}_{2}$ production by human neutrophils}

$\mathrm{H}_{2} \mathrm{O}_{2}$ production by neutrophils was measured using the scopoletin/ HRP fluorescence technique [25,26]. Briefly, a suspension of neutrophils $\left(2 \times 10^{6}\right.$ cells $/ \mathrm{ml}$ in PBS supplemented with $1 \mathrm{mM} \mathrm{CaCl}_{2}$ and $0.5 \mathrm{mM} \mathrm{MgCl}_{2}$ ) was mixed with $1 \mu \mathrm{M}$ scopoletin (a fluorescent substrate of HRP), $20 \mu \mathrm{g} / \mathrm{ml}$ horseradish peroxidase, and $1 \mathrm{mM} \mathrm{NaN}_{3}$ (catalase and myeloperoxidase inhibitor). The cell suspension was incubated for $5 \mathrm{~min}$ at $37^{\circ} \mathrm{C}$ in a cuvette of a fluorimeter CM 2203 (SOLAR, Minsk, Belarus) and then test reagents were added as required. A decrease in fluorescence of scopoletin was monitored at $460 \mathrm{~nm}$ (excitation at 
$350 \mathrm{~nm}$ ) and the maximal slope of the recorded traces was used to quantify the rate of $\mathrm{H}_{2} \mathrm{O}_{2}$ generation by cells.

\subsection{Assays for degranulation of human neutrophils}

Two assays were used to assess degranulation of neutrophils based on the detection of myeloperoxidase (MPO) and lysozyme releasing into extracellular medium from cells $\left(3 \times 10^{6}\right.$ cells $/ \mathrm{ml}$ in PBS supplemented with $1 \mathrm{mM} \mathrm{CaCl} 2$ and $\left.0.5 \mathrm{mM} \mathrm{MgCl}_{2}\right)$ treated with $\operatorname{rhLf}(250 \mu \mathrm{g} / \mathrm{ml})$ for $15 \mathrm{~min}$ at $37^{\circ} \mathrm{C}$. Samples for testing MPO release were additionally treated with cytochalasin $\mathrm{B}(2.5 \mu \mathrm{g} / \mathrm{ml})$. The degranulation reaction was stopped by placing the samples on ice and subsequent centrifugation for $8 \mathrm{~min}$ at $2,500 \mathrm{xg}$. Lysozyme activity in supernatants was measured by detecting the lysis of the bacterial cells M. lysodeikticus using light transmission assay as described elsewhere [27,28]. MPO activity in the supernatants was measured spectrophotometrically using $o$-DA and $\mathrm{H}_{2} \mathrm{O}_{2}$ substrates as previously described [29]. To examine calciumdependent regulation of degranulation responses, neutrophils were maintained at $37{ }^{\circ} \mathrm{C}$ and pretreated with either EDTA $(1 \mathrm{mM})$ for $5 \mathrm{~min}$, or with BAPTA $(10 \mu \mathrm{M})$ and EDTA for $30 \mathrm{~min}$ before adding rhLf.

\subsection{Measurements of cytoplasmic calcium}

Measurements of cytoplasmic $\mathrm{Ca}^{2+}\left(\left[\mathrm{Ca}^{2+}\right]_{\mathrm{i}}\right)$ in human neutrophils were performed using the fluorescent $\mathrm{Ca}^{2+}$ indicator fura-2AM as described elsewhere $[24,30]$. Neutrophils were resuspended in isotonic HEPES-buffered saline containing $120 \mathrm{mM} \mathrm{NaCl}, 4.7 \mathrm{mM} \mathrm{KCl}, 1.2 \mathrm{mM}$ $\mathrm{KH}_{2} \mathrm{PO}_{4}, 4.4 \mathrm{mM} \mathrm{Mg}_{2} \mathrm{SO}_{4}, 1.7 \mathrm{mM} \mathrm{CaCl}_{2}, 11 \mathrm{mM}$ D-glucose, and $20 \mathrm{mM}$ HEPES, pH 7.4 (HEPES buffer) and loaded with $2 \mu \mathrm{M}$ fura-2AM for $40 \mathrm{~min}$ at $37^{\circ} \mathrm{C}$. The cells were then washed 3 times in HEPES buffer without $\mathrm{CaCl}_{2}$, resuspended at a concentration of $10^{7}$ cells $/ \mathrm{ml}$, placed on ice, and used within $3 \mathrm{~h}$. To measure fluorescence, cells were resuspended in $1 \mathrm{ml}$ HEPES buffer with or without calcium at a concentration of $10^{6}$ cells $/ \mathrm{ml}$ and preincubated at $37^{\circ} \mathrm{C}$ for $5 \mathrm{~min}$ prior to adding test reagents. All fluorescence measurements were performed using a spectrofluorimeter CM 2203 (SOLAR, Minsk, Belarus) in cell samples undergoing constant gentle stirring. Fluorescence kinetics were recorded at $510 \mathrm{~nm}$ (excitation at $340 \mathrm{~nm}$ and $380 \mathrm{~nm}$ ) and changes in $\left[\mathrm{Ca}^{2+}\right]_{\mathrm{i}}$ were assessed based on the ratiometric calibration method [31]. To be sure that the effects of rhLf are not related to endotoxin contamination, rhLf sample was preincubated with polymyxin B $(10 \mu \mathrm{g} / \mathrm{ml})$.

\subsection{Staining of the actin cytoskeleton}

The coverslips used in actin cytoskeleton staining assay were cleaned with $70 \%$ alcohol. To prepare human neutrophils for staining the actin cytoskeleton structures, cells were fixed with $4 \%$ paraformaldehyde in PBS for $10 \mathrm{~min}$ and attached to poly-L-lysine-coated glass slides over a $15 \mathrm{~min}$ drying step. Next, the attached cells were permeabilized for 5 min with $0.1 \%$ Triton X-100 in PBS and rinsed three times with PBS. To visualize F-actin, cells were stained with Alexa Fluor 488 phalloidin $(0.17 \mu \mathrm{M})$ in the dark for $40 \mathrm{~min}$ at room temperature and washed two times with PBS and once with distilled water before mounting the slides using Fluoromount ${ }^{\mathrm{TM}}$ aqueous mounting medium. Images were acquired using a laser scanning confocal microscope NanoFinder30 (Tokio Instruments, Japan) and processed using the NanoFinder Data Viewer.

\subsection{Lectin-induced adherence junctions}

Plant lectins are strong inducers of cell aggregation [32], which is often associated with formation of relatively stable cell-cell contacts or specific adherence junctions being resistant to inhibitory haptenic sugars (HSR contacts) [33,34]. To induce the formation of HSR contacts, human neutrophils in suspension $\left(2 \times 10^{6}\right.$ cells $/ \mathrm{ml}$ in PBS supplemented with $1 \mathrm{mM} \mathrm{CaCl} 2$ and $0.5 \mathrm{mM} \mathrm{MgCl}_{2}$ ) were treated with either STA $(50 \mu \mathrm{g} / \mathrm{ml})$ or WGA $(2.5 \mu \mathrm{g} / \mathrm{ml})$ and the cell aggregation was recorded at $37^{\circ} \mathrm{C}$ for $3-4 \mathrm{~min}$ using an optical aggregometer AP2110 (SOLAR, Minsk, Belarus). Next, inhibitory haptenic sugars of STA $(1.6 \%$ chitin hydrolysate) or WGA (100 mM GlcNAc) were added to induce dissociation of cell aggregates. A stationary light transmission of cell aggregates in the presence of haptenic sugars was used as an indicator of HSR contacts and calculated as a percentage of the initial light transmission of lectin-induced cell aggregates.

\subsection{Statistical analysis}

Statistical analysis was performed using Origin 7.0 (OriginLab, Northampton, Massachusetts, USA) and included unpaired Student's $t$ test or one-way ANOVA and post hoc Tukey's HSD test as indicated to analyze differences between means and Pearson's correlation coefficient to measure the statistical relationship between our variables. Values of $p<0.05$ were considered to indicate statistically significant differences. All data were presented as mean \pm standard error of the mean (SEM).

\section{Results}

\subsection{Binding of rhLf to human neutrophils and calcium responses}

Flow cytometry analysis revealed efficient binding of rhLf-FITC to human neutrophils, as evidenced by a significant shift in the fluorescence intensity of the labeled cells (Fig. 1A). To explore a functional context of this binding, we examined the effects of rhLf on cytosolic calcium as an indicator of early receptor-mediated responses of neutrophils [35-37]. As shown in Fig. 1B, treatment of neutrophils with rhLf $(250 \mu \mathrm{g} / \mathrm{ml})$ in calcium-containing medium caused an increase in $\left[\mathrm{Ca}^{2+}\right]_{\mathrm{i}}$ lasting for 30-60 s. This effect was sustained in the presence of $10 \mu \mathrm{g} / \mathrm{ml}$ polymyxin $\mathrm{B}\left(\left[\mathrm{Ca}^{2+}\right]_{\mathrm{i}}\right.$ rise was $278 \pm 38 \mathrm{nM}$ in control versus $241 \pm 24 \mathrm{nM}$ in polymyxin B-treated cells, $\mathrm{n}=5$ ) excluding a presence of endotoxin contamination of our protein samples. The calcium response of neutrophils to rhLf also showed a dose-dependent increase, reaching a plateau at concentrations of rhLf above $250 \mu \mathrm{g} / \mathrm{ml}$ (Fig. 1C).

Extracellular calcium contributed significantly to rhLf-induced cytoplasmic calcium increase because the response in calcium-free medium containing $\mathrm{Ca}^{2+}$-chelator EDTA $(1 \mathrm{mM})$ was much weaker in comparison with $\mathrm{Ca}^{2+}$-containing medium (Fig. $1 \mathrm{~B}$ and D). Accordingly, subsequent addition of $\mathrm{CaCl}_{2}(2 \mathrm{mM})$ to the cell suspension induced a further increase in cytoplasmic $\mathrm{Ca}^{2+}$ levels in rhLf-treated neutrophils (Fig. 1B). In addition, treatment of cells with $2 \mu \mathrm{M}$ thapsigargin (an inhibitor of sarco/endoplasmic reticulum $\mathrm{Ca}^{2+}$-ATPase [38]) induced $\mathrm{Ca}^{2+}$ increase on $105 \pm 31 \mathrm{nM}$ due to its leakage from the ER, however, no response to rhLf was observed in this case. As the elevation of cytoplasmic calcium can be due to $\mathrm{Ca}^{2+}$-release from the intracellular depot and/or $\mathrm{Ca}^{2+}$-entry from the extracellular medium $[39,40]$, we suggest that binding rhLf to human neutrophils and subsequent transmembrane signaling may involve the store-operated $\mathrm{Ca}^{2+}$ entry (SOCE) pathway and $\mathrm{Ca}^{2+}$ ATP-powered P-pumps of the endoplasmic reticulum $[41,42]$. To gain more insights into this regulation, we used a pharmacological approach and treated neutrophils with drugs affecting specific $\mathrm{Ca}^{2+}$-channels or signal transduction enzymes. We observed that in the $\mathrm{Ca}^{2+}$-containing medium $\mathrm{NiCl}_{2}$ (an inhibitor of T-type $\mathrm{Ca}^{2+}$ channels), genistein (an inhibitor of tyrosine kinases), and U73122 (phospholipase C inhibitor) significantly inhibited the $\mathrm{Ca}^{2+}$ inducing effect of rhLf whereas $( \pm$ )-methoxyverapamil (an inhibitor of voltage-dependent $\mathrm{Ca}^{2+}$ channels) and wortmannin (an inhibitor of phosphatidylinositol-3-kinases) had no effects. Considering all limits of biochemical inhibitors, these findings suggest that tyrosine kinases and phospholipase $\mathrm{C}$ are likely associated with rhLf-induced calcium signaling in human neutrophils.

Calcium signaling is important for many inherent functions of 
A

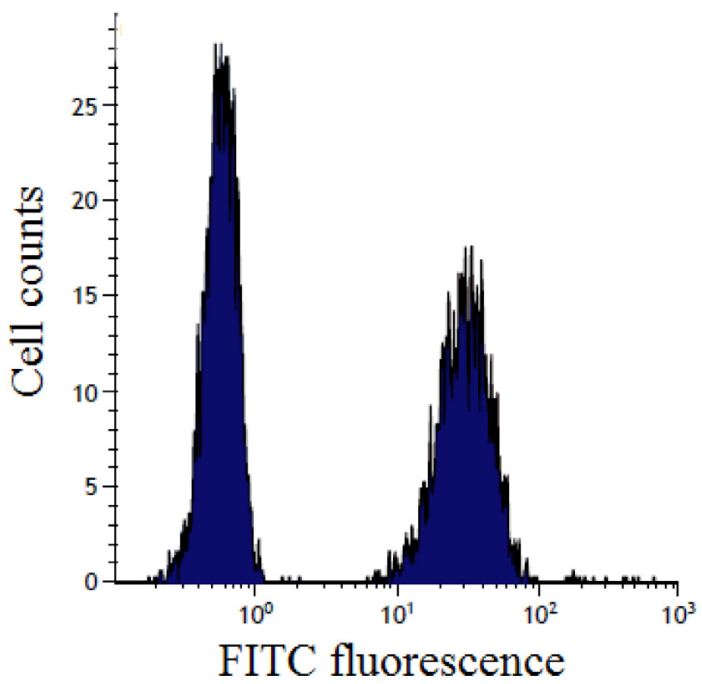

C

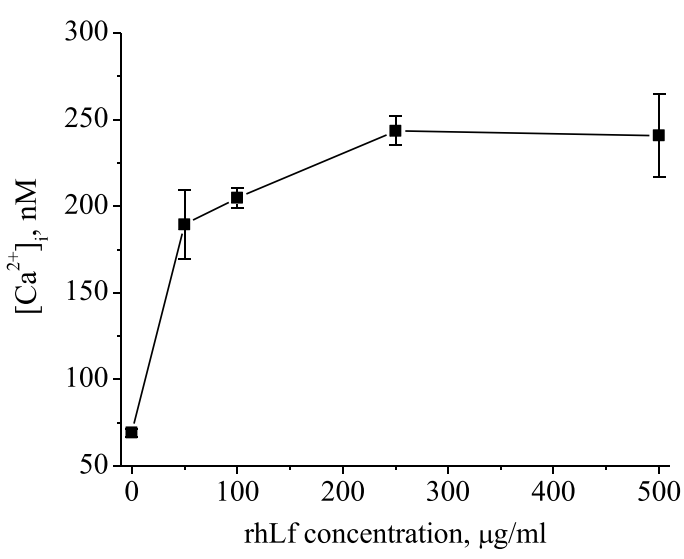

B

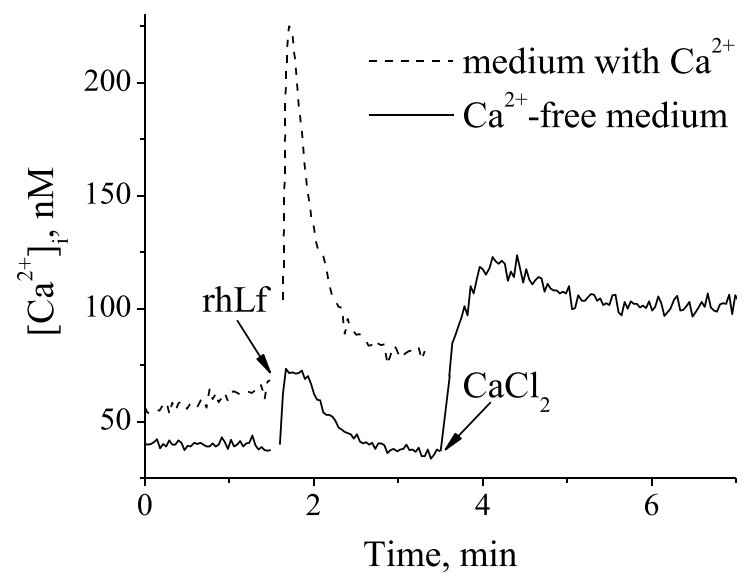

D

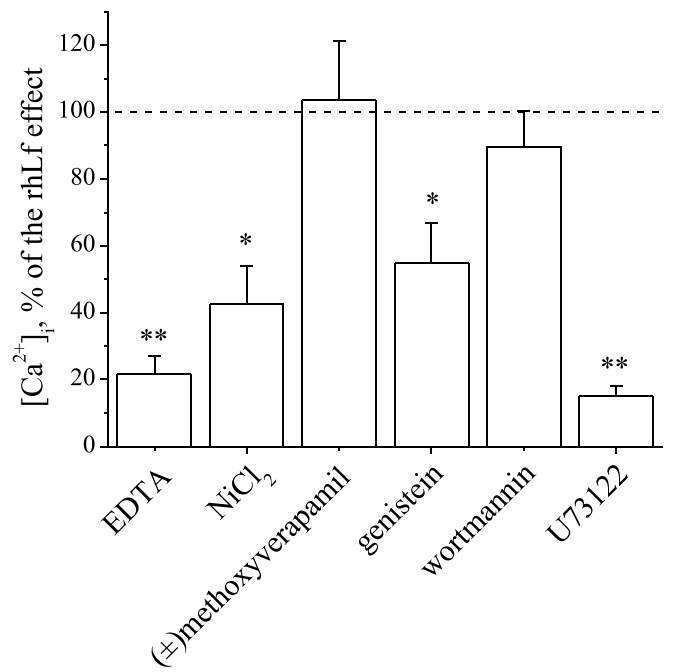

Fig. 1. Binding of rhLf to human neutrophils and calcium responses. A, Histogram of fluorescence intensity of rhLf (baseline) and rhLf-FITC, bound to neutrophils (fluorescence excitation $-488 \mathrm{~nm}$, emission $-525 \mathrm{~nm}$ ). Experiments were carried out in $\mathrm{Ca}^{2+}$-containing medium and at least 5000 neutrophils were analyzed in each sample. Data are shown for one of three independent experiments. B, rhLf induces a transient increase of $\mathrm{Ca}^{2+}$ concentration in the cytoplasm of neutrophils that depends on the presence of extracellular $\mathrm{Ca}^{2+}$. Fura-2-loaded neutrophils $\left(1 \times 10^{6}\right.$ cells/ml $)$ were incubated for 3 min at $37^{\circ} \mathrm{C}$ and then treated with rhLf $(250 \mu \mathrm{g} / \mathrm{ml})$ in medium containing $1.7 \mathrm{mM} \mathrm{CaCl}_{2}$ (dashed line) and in $\mathrm{Ca}^{2+}$-free medium containing $1 \mathrm{mM}$ EDTA (solid line). The arrows indicate the moments of rhLf or $\mathrm{CaCl}_{2}(2 \mathrm{mM})$ addition to the suspension of neutrophils. C, dose-dependent effects of rhLf on the cytoplasmic calcium increase. Neutrophils were stimulated by different concentrations of rhLf $(62.5-500 \mu \mathrm{g} / \mathrm{ml})$ in $\mathrm{Ca}^{2+}$-containing medium. D, Effects of biochemical inhibitors on rhLf-induced $\left[\mathrm{Ca}^{2+}\right]_{\mathrm{i}}$ increase in human neutrophils. Cells were pre-incubated for $5 \mathrm{~min}$ at $37^{\circ} \mathrm{C}$ with EDTA $(1 \mathrm{mM}), \mathrm{NiCl}_{2}(1 \mathrm{mM}),( \pm$ )-methoxyverapamil $(100 \mu \mathrm{M})$, genistein $(10 \mu \mathrm{M})$, wortmannin $(100 \mathrm{nM})$, or U73122 $(620 \mathrm{nM})$ followed by adding rhLf $(250 \mu \mathrm{g} / \mathrm{ml})$. All experiments were performed in $\mathrm{Ca}^{2+}$-containing medium except for the assay with EDTA conducted in a $\mathrm{Ca}^{2+}$-free medium. All data are presented as means $\pm \mathrm{SEM}, \mathrm{n}=5-7 .{ }^{*} p<0.05,{ }^{* *} p<0.01$ versus control cells untreated with inhibitors (by oneway ANOVA and post hoc Tukey's HSD test).

neutrophils in innate immunity including the production of toxic reactive oxygen species (ROS) (respiratory burst), degranulation or exocytosis of granular enzymes, and cell adhesion [43-45]. Considering this conceptual point, we examined the role of intracellular calcium in mediating the effects of rhLf on the functional responses of neutrophils.

\subsection{Inhibition of rhLf-induced degranulation of human neutrophils by $\mathrm{Ca}^{2+}$-chelators}

Treatment of human neutrophils for $15 \mathrm{~min}$ with $\mathrm{rhLf}(250 \mu \mathrm{g} / \mathrm{ml})$ induced the release of enzymes from two different types of intracellular granules (exocytosis) including MPO (component of azurophilic granules) and lysozyme (component of specific granules) (Fig. 2A and B). In both cases, these functional responses were inhibited by a cellpermeable $\mathrm{Ca}^{2+}$-chelator BAPTA $(10 \mu \mathrm{M})$ and non-permeable $\mathrm{Ca}^{2+}$ chelator EDTA $(1 \mathrm{mM})$. The general requirement of calcium for rhLfinduced degranulation of human neutrophils questioned the involvement of the actin cytoskeleton as a well-known factor in this regulation [46-48]. Therefore, we examined the effects of rhLf $(250 \mu \mathrm{g} / \mathrm{ml})$ on Factin distribution in cells stained with Alexa Fluor 488 phalloidin using confocal fluorescence microscopy. Indeed, a significant remodeling of the actin cytoskeleton was evident in rhLf-treated human neutrophils within 10 min so that a strong overall cortical actin staining in control changed to a clustered staining only at one site, indicated cell 
A

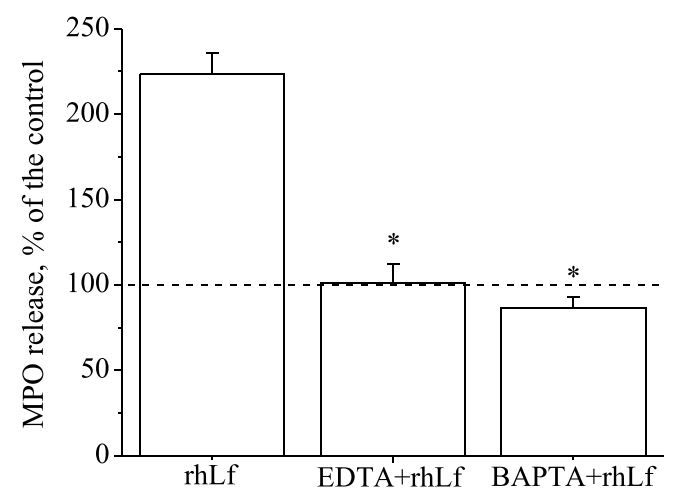

C
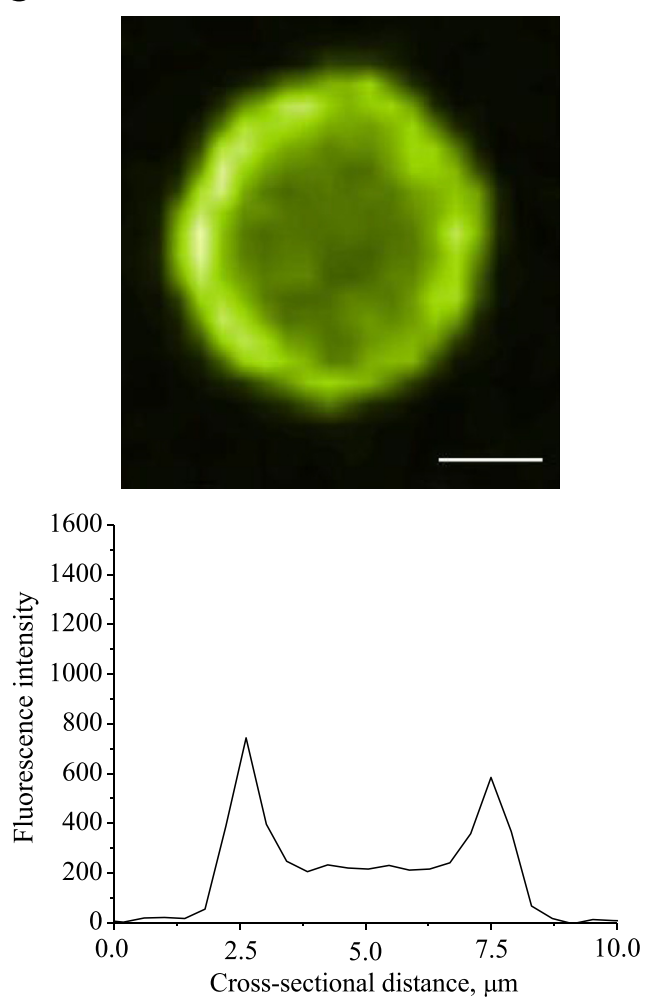

B

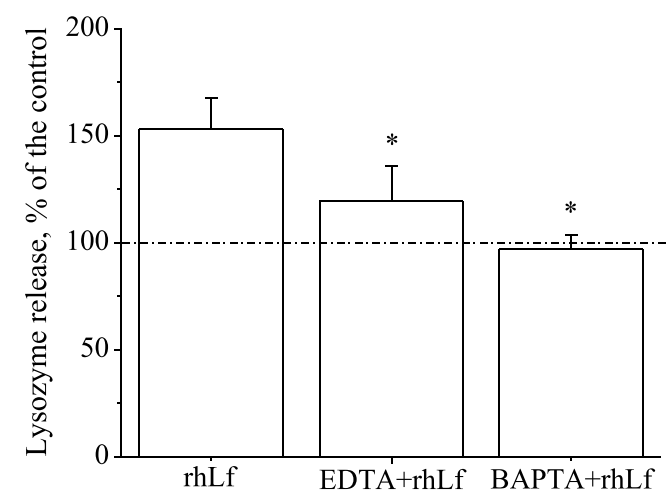

D
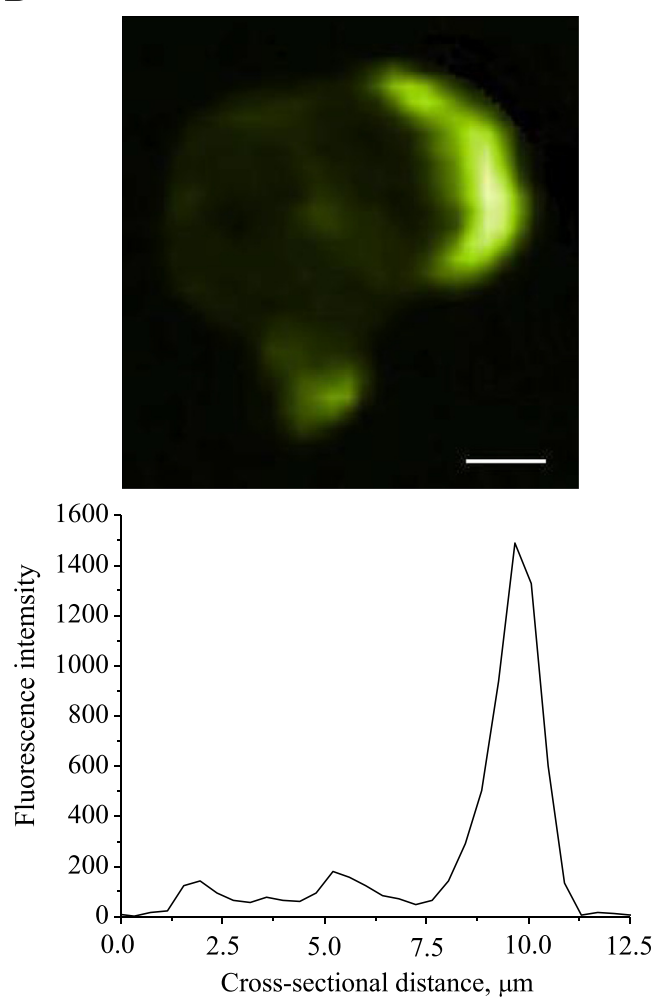

Fig. 2. rhLf induces human neutrophil degranulation in calcium-dependent manner and remodels of actin cytoskeleton. A and B, Effects of rhLf on MPO and lysozyme release from human neutrophils in $\mathrm{Ca}^{2+}$-containing medium (PBS supplemented with $1 \mathrm{mM} \mathrm{CaCl} \mathrm{C}_{2}$ and $0.5 \mathrm{mM} \mathrm{MgCl}_{2}$ ) and in Ca ${ }^{2+}$-exhausted medium (supplemented with $\mathrm{Ca}^{2+}$ chelators, $1 \mathrm{mM}$ EDTA or $10 \mu \mathrm{M}$ BAPTA-AM). Data (means \pm SEM, $n=3-5$ ) represent the levels of the secreted enzymes in cell-free supernatants at $15 \mathrm{~min}$ exposure of human neutrophils $\left(3 \times 10^{6}\right.$ cells $\left./ \mathrm{ml}\right)$ to rhLf $(250 \mu \mathrm{g} / \mathrm{ml})$ as described in Material and Methods. * $p<0.05$ versus control cells (by one-way ANOVA and post hoc Tukey's HSD test). $\mathbf{C}$ and $\mathbf{D}$, Changes in morphology of the actin cytoskeleton in human neutrophils treated with rhLf. To visualize F-actin, the cells were treated and stained with Alexa Fluor 488 phalloidin as described in Material and Methods. C - a control cell, D - a cell exposed to rhLf (250 $\mu$ / $\mathrm{ml}$ ) for $10 \mathrm{~min}$ at $37^{\circ} \mathrm{C}$. The middle cross-section profiles of F-actin staining are shown below the microphotographs. Scale bars, $2 \mu \mathrm{m}$.

polarization (Fig. 2C and D, Supplementary Materials, Fig. S1).

\subsection{Effects of rhLf on neutrophil respiratory burst}

Respiratory burst of neutrophils (production of ROS by the phagocyte NADPH-oxidase) can be induced by many soluble stimuli such as fMLP, A23187, and plant lectins, the efficiency of which depends on cytoplasmic calcium [49-52]. Treatments of human neutrophils with rhLf $(250 \mu \mathrm{g} / \mathrm{ml})$ alone failed to induce $\mathrm{H}_{2} \mathrm{O}_{2}$ generation as per HRPmediated scopoletin oxidation. However, rhLf modified neutrophil responses to well-known $\mathrm{H}_{2} \mathrm{O}_{2}$-inducing agonists as exemplary shown for
WGA in Fig. 3A. More specifically, rhLf augmented $\mathrm{H}_{2} \mathrm{O}_{2}$ production by neutrophils in response to $\mathrm{AMLP}$, WGA, and PHA-L, inhibited in response to Con A, VSA, SNA, PNA, SBA and STA, and showed no effects on PMA and CABA responses (Fig. 3B). All these agonists have different biochemical properties (Supplementary Materials, Figs. S2 and S3) and might use different mechanisms for activating the phagocyte NADPHoxidase. Indeed, fMLP, WGA, Con A, PHA-L, and CABA induced significant increase of $\left[\mathrm{Ca}^{2+}\right]_{\mathrm{i}}$, while no $\left[\mathrm{Ca}^{2+}\right]_{\mathrm{i}}$ changes were observed in the presence of PMA, VSA, PNA, SBA and STA (Fig. 3C). However, Pearson's coefficient showed a significant correlation $(\mathrm{R}=0.878$, $\mathrm{p}<0.001, \mathrm{n}=11$ ) between the $\left[\mathrm{Ca}^{2+}\right]_{\mathrm{i}}$ and $\mathrm{H}_{2} \mathrm{O}_{2}$ production in the 
A

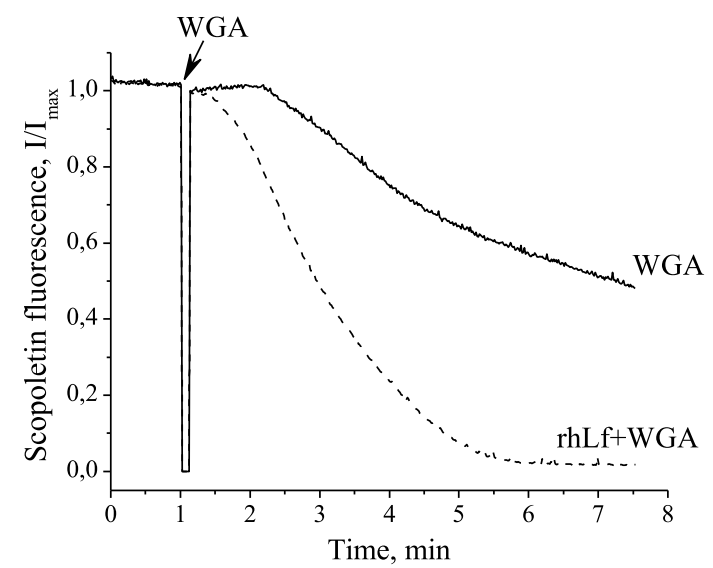

C

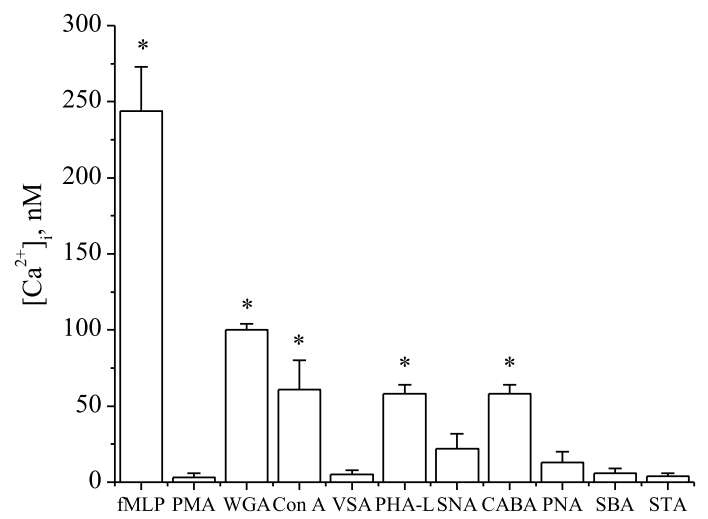

B

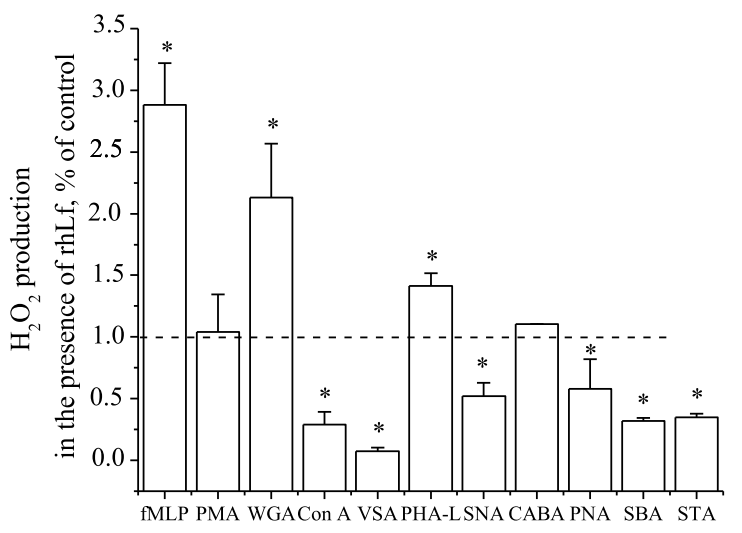

D

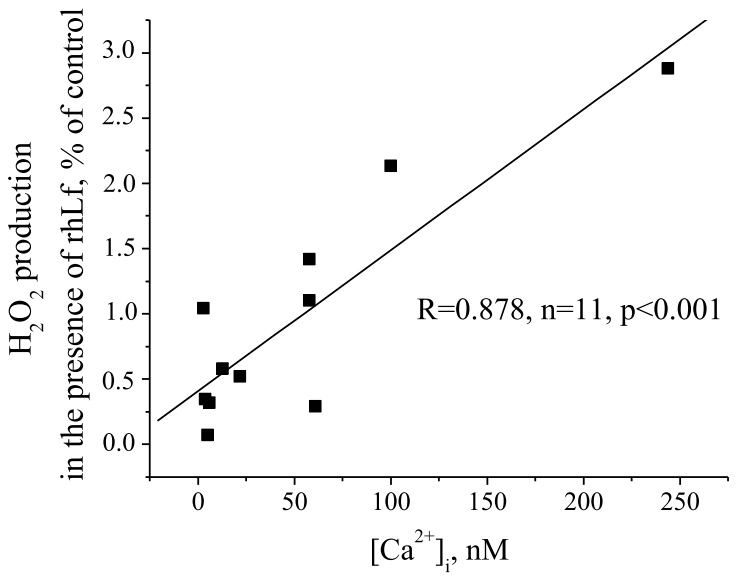

Fig. 3. Calcium-dependent effects of rhLf on agonist-induced generation of $\mathrm{H}_{2} \mathrm{O}_{2}$ by human neutrophils. A, Typical kinetics of scopoletin oxidation by human neutrophils in response to WGA $(50 \mu \mathrm{g} / \mathrm{ml})$ in the absence (solid line) or in the present (dashed line) of rhLf ( $250 \mu \mathrm{g} / \mathrm{ml})$. The suspension of neutrophils in PBS with $1 \mathrm{mM} \mathrm{CaCl}{ }_{2}$ and $0.5 \mathrm{mM} \mathrm{MgCl}_{2}\left(2 \times 10^{6}\right.$ cells/ml) contained $1 \mu \mathrm{M}$ scopoletin, $20 \mu \mathrm{g} / \mathrm{ml} \mathrm{HRP}$, and $1 \mathrm{mM} \mathrm{NaN}$. Measurements were performed as described in Material and Methods by measuring fluorescence intensity at $460 \mathrm{~nm}$ (excitation was at $350 \mathrm{~nm}$ ). B, Effects of rhLf on $\mathrm{H}_{2} \mathrm{O}_{2}$ production by human neutrophils induced by different agonists. The rate of $\mathrm{H}_{2} \mathrm{O}_{2}$ production was calculated based on scopoletin oxidation kinetics similar to those shown in A. The agonists were used at concentrations of $10 \mathrm{nM}$ (PMA), $100 \mathrm{nM}$ (fMLP), and $50 \mu \mathrm{g} / \mathrm{ml}$ (all plant lectins). Data (means \pm SEM, $\mathrm{n}=3-5$ ) represent the rates of scopoletin oxidation for each agonist in the presence of rhLf $(250 \mu \mathrm{g} / \mathrm{ml})$ normalized to the relevant control without rhLf. ${ }^{*} p<0.05$ versus control (one-sample $t$-test). C, The peak values of $\left[\mathrm{Ca}^{2+}\right]_{\mathrm{i}}$ rise in human neutrophils, activated by various agonists. Fura-2-loaded neutrophils $\left(1 \times 10^{6} \mathrm{cells} / \mathrm{ml}\right)$ in PBS containing $1.7 \mathrm{mM}$ CaCl 2 were stimulated at $37^{\circ} \mathrm{C}$ with the same agonists as listed in B $(100 \mathrm{nM}$ fMLP, $10 \mathrm{nM}$ PMA, or plant lectins at $50 \mu \mathrm{g} / \mathrm{ml})$. All data are represented as the mean \pm SEM, $\mathrm{n}=3-5$. $* p<0.05$ versus the basal level of cytoplasmic calcium level (by one-way ANOVA and post hoc Tukey's HSD test). D, Positive correlation between cytoplasmic calcium and changes in $\mathrm{H}_{2} \mathrm{O}_{2}$ production by human neutrophils in the presence of rhLf $(\mathrm{R}=0.878, \mathrm{n}=11, \mathrm{p}<0.001)$. Combined data from $\mathbf{B}$ and $\mathrm{C}$ were used to run the Pearson's correlation test.

presence of rhLf (Fig. 3D).

\subsection{Effects of rhLf on adherence junctions in neutrophils}

Activation and adhesion of neutrophils to the endothelium near the sites of inflammation or infection is an important aspect of innate immunity [53,54]. Lectin-induced aggregation of neutrophils mimics, with some limitations, this process based on the formation of HSRcontacts between cells $[30,33,55,56]$. Two GlcNAc-specific plant lectins STA $(50 \mu \mathrm{g} / \mathrm{ml})$ or WGA $(2.5 \mu \mathrm{g} / \mathrm{ml})$ induced neutrophil aggregation and the formation of HSR contacts, which were evident in the presence of chitin hydrolysate $(1.6 \%)$ or GlcNAc $(100 \mathrm{mM})$, respectively (Fig. 4A and B). We observed no cell aggregation induced directly by rhLf
$(100 \mu \mathrm{g} / \mathrm{ml})$, however the lectin-induced HSR-contacts were significantly enhanced by rhLf (Fig. 4C). The similar stabilizing effect of rhLf was observed in an alternate model of neutrophil aggregation induced by fMLP (Fig. 4D). Thus, rhLf promotes the formation of adherence junctions in neutrophils activated with different types of agonists.

\section{Discussion}

Lf is a multifunctional molecule with many health-beneficial properties justifying therapeutic and nutraceutical uses of this protein $[57,58]$. Different types of Lf are available for applied purposes including native forms isolated from milk and recombinant forms from 
A

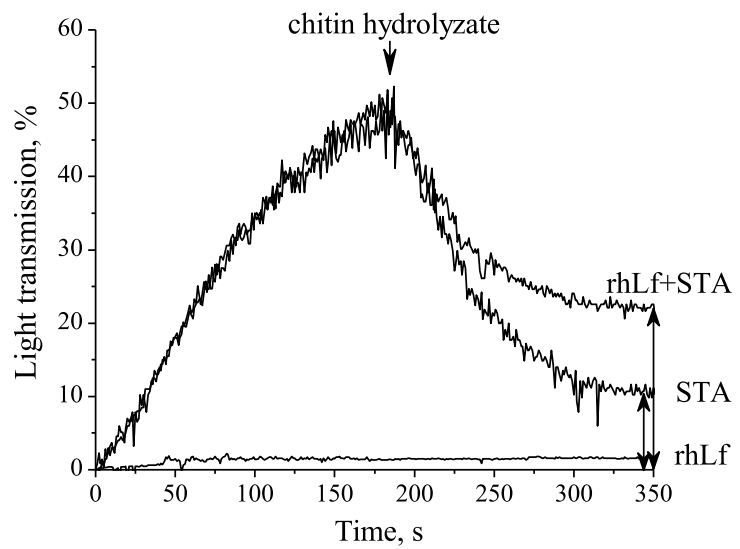

C

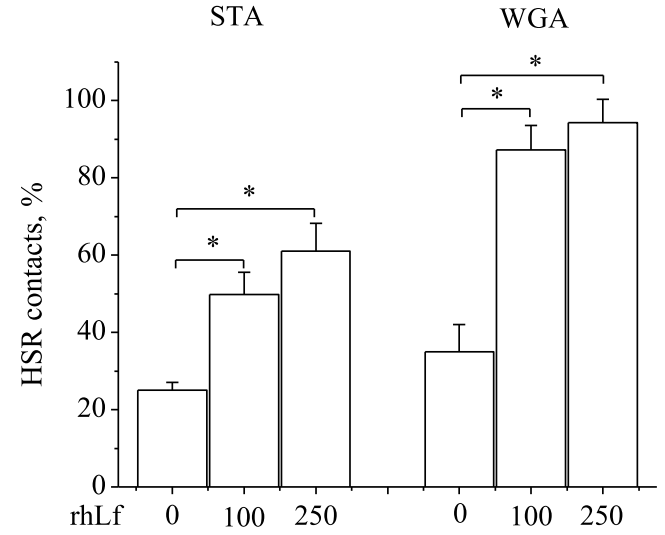

B

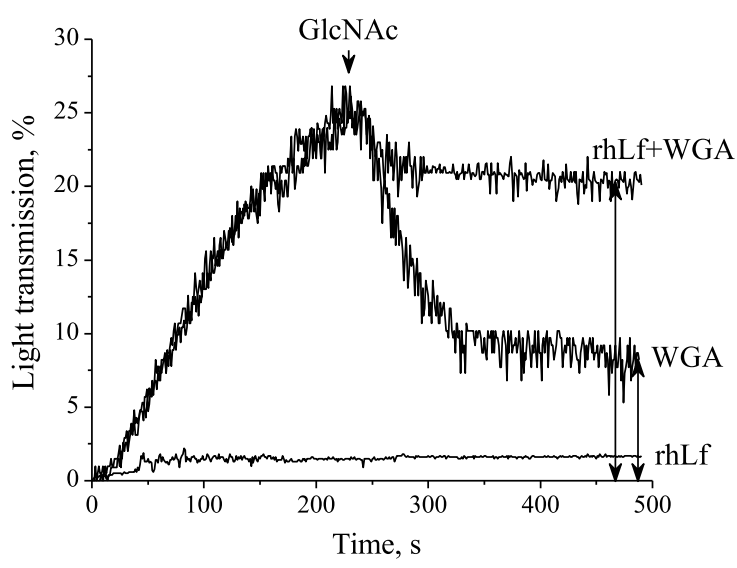

D

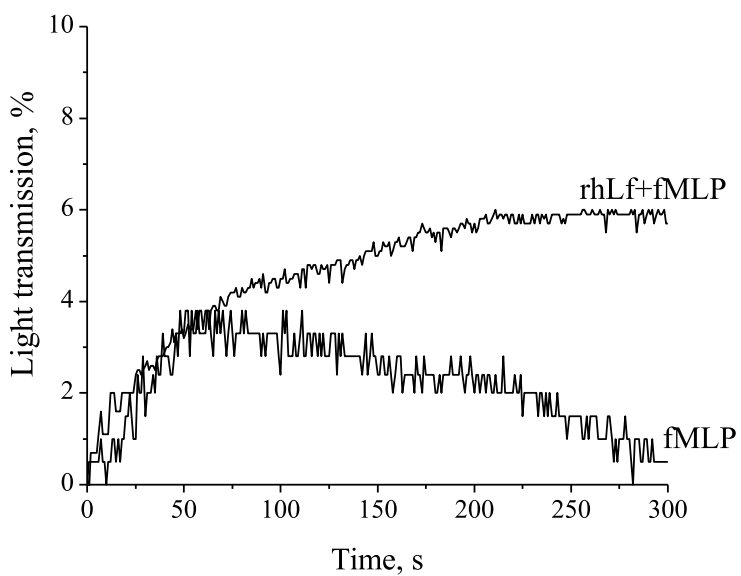

Fig. 4. Effects of rhLf on the formation of adherence junctions (HSR contacts) in human neutrophils. A and B, Typical kinetics of human neutrophil aggregation induced by STA $(50 \mu \mathrm{g} / \mathrm{ml})$ and WGA $(2.5 \mu \mathrm{g} / \mathrm{ml})$. Cell aggregates were partially dissociated by relevant inhibitory sugars such as chitin hydrolysate $(1.6 \%)$ for STA and GlcNAc $(100 \mathrm{mM})$ for WGA, however rhLf $(100 \mu \mathrm{g} / \mathrm{ml})$ readily declined the dissociation response. All measurements were performed at $37^{\circ} \mathrm{C}$ as described in Material and Methods. C, HSR contacts of STA- and WGA-induced neutrophil aggregates in absence (control) and in the presence of rhLf (100 $\mu \mathrm{g} / \mathrm{ml}$ and $250 \mu \mathrm{g} / \mathrm{ml}$ ). ${ }^{*} p<0.05$ versus control (Student's $t$-test for independent samples). D, Typical kinetics of human neutrophil aggregation induced by fMLP (100 nM) in the absence and in the presence of rhLf $(100 \mu \mathrm{g} / \mathrm{ml})$.

plant, mammalian cell, and yeast expression systems [59]. In this work, we verified and attested biological activity of rhLf isolated from milk of transgenic goats using human neutrophils as effector cells of innate immunity.

Our findings indicate that rhLf from transgenic goat milk is a priming agonist of human neutrophils, which binds to the cells and induces or facilitates a variety of immediate functional responses including the elevation of cytoplasmic calcium, cell degranulation (exocytosis of MPO and lysozyme), modulation of $\mathrm{H}_{2} \mathrm{O}_{2}$ production, and enhancement of cell junctions. Majority of these responses are welldescribed for native human Lf. For example, human Lf translocated from the specific granules to the neutrophil plasma membrane enhances adherence of neutrophils to endothelial cells [19]. Lf from human colostrum primes in a dose dependent manner superoxide production by neutrophils in response to fMLP and opsonized zymosan [15]. Although neutrophils are responsible for killing invading pathogens and immediate host defenses during tissue infection, excessive production of cytotoxic substances may have a deleterious effect in magnifying the local inflammation [60]. In this context, rhLf is a mild regulator of neutrophils functions, which mostly primes rather than directly activates neutrophil adhesion and generation of ROS. It is essential that the migration of neutrophils from circulation into an area of inflammation or infection is also accompanied by degranulation [61]. Here we demonstrated that rhLf at high concentrations that are characteristic for foci of inflammation induced the exocytosis of MPO and lysozyme. The ability of rhLf to activate neutrophils was supported by the observation that this protein initiated calcium responses and F-actin redistribution in cells. To the best of our knowledge, this is the first report of calcium-inducing properties of rhLf which stimulates an increase in neutrophil cytosolic calcium through both the release of $\mathrm{Ca}^{2+}$ from endoplasmic reticulum and $\mathrm{Ca}^{2+}$ entry across the plasma membrane. Furthermore, our findings suggest that rhLf-induced calcium signaling might be indispensable for mild priming of such essential functional responses of neutrophils as $\mathrm{H}_{2} \mathrm{O}_{2}$ generation and degranulation. Calcium is a universal intracellular messenger [40] and molecular mechanisms of the relevant rhLf-mediated regulation remain to be elucidated. Considering the screening of several biochemical inhibitors in our study, the role of tyrosine kinases and phospholipase $\mathrm{C}$ deserves further elaboration in the context of rhLf-induced calcium mobilization in human neutrophils. 
An important novel aspect of biological activity of rhLf is its ability to stimulate adherens junctions (HSR contacts) between neutrophils in lectin-induced cell aggregates. Apparently, this can occur either due to increased ROS production or due to increased cytosolic $\mathrm{Ca}^{2+}$ in neutrophils, both of which are complementary agonists of cell adhesion $[30,56,62,63]$. Another reason of the enhanced stability of neutrophil aggregates could be the expression of additional adhesion receptors such as CD11b/CD18 integrins [64] on the neutrophil surface as a result of rhLf-induced degranulation. Further studies are required to examine these mechanisms and the role of rhLf in enhancing homo- and heterotypic adhesion of human neutrophils.

In conclusion, our findings indicate that rhLf regulates a range of neutrophil functions (degranulation, $\mathrm{H}_{2} \mathrm{O}_{2}$ generation, and cell adhesion) and provide new insights into the contribution of rhLf to the innate immunity. This protein binds to neutrophils and induces immediate responses resulting from cytoplasmic calcium increase and Factin redistribution. As such, rhLf from transgenic goat milk represents a fully functional protein in a model system of human neutrophils and add to the line of new recombinant proteins for biomedical and biotechnological applications.

\section{Declaration of competing interest}

The authors declare that they have no conflict of interest.

\section{Acknowledgements}

This work was partly supported by RFBR (grant 18-515-00004), BRFBR (grant B18R-058) and Russian President's grant MD5133.2018.4.

\section{Appendix A. Supplementary data}

Supplementary data to this article can be found online at https:// doi.org/10.1016/j.abb.2019.108122.

\section{References}

[1] P.P. Ward, E. Paz, O.M. Conneely, Multifunctional roles of lactoferrin: a critical overview, Cell. Mol. Life Sci. 62 (2005) 2540-2548 https://doi.org/10.1007/ s00018-005-5369-8.

[2] I.A. García-Montoya, T.S. Cendón, S. Arévalo-Gallegos, Q. Rascón-Cruz, Lactoferrin a multiple bioactive protein: an overview, Biochim. Biophys. Acta 1820 (2012) 226-236 https://doi.org/10.1016/j.bbagen.2011.06.018.

[3] S.H. Wong, N. Francis, H. Chahal, K. Raza, M. Salmon, D. Scheel-Toellner, J.M. Lord, Lactoferrin is a survival factor for neutrophils in rheumatoid synovial fluid, Rheumatology 48 (2009) 39-44 https://doi.org/10.1093/rheumatology/ ken412.

[4] S. Baveye, E. Elass, D.G. Fernig, C. Blanquart, J. Mazurier, D. Legrand, Human lactoferrin interacts with soluble CD14 and inhibits expression of endothelial adhesion molecules, E-selectin and ICAM-1, induced by the CD14-lipopolysaccharide complex, Infect. Immun. 68 (2000) 6519-6525 https://doi.org/10.1128/iai.68.12. 6519-6525.2000.

[5] M.L. Kruzel, J.K. Actor, I. Boldogh, M. Zimecki, Lactoferrin in health and disease, Postepy Hig. Med. Dosw. 61 (2007) 261-267.

[6] G. Trybek, M. Metlerski, K. Szumilas, M. Aniko-Włodarczyk, O. Preuss, K. Grocholewicz, B. Wiszniewska, The biological properties of lactoferrin, Cent. Eur. J. Sport Sci. Med. 15 (2016) 25-35 https://doi.org/10.18276/cej.2016.3-03.

[7] L. Adlerova, A. Bartoskova, M. Faldyna, Lactoferrin: a review, Vet. Med. 53 (2008) 457-468 https://doi.org/10.17221/1978-VETMED.

[8] D. Legrand, E. Elass, M. Carpentoer, J. Mazurier, Lactoferrin: a modulator of immune and inflammatory responses, Cell. Mol. Life Sci. 62 (2005) 2549-2559 https://doi.org/10.1007/s00018-005-5370-2.

[9] Y.A. Suzuki, B. Lönnerdal, Characterization of mammalian receptors for lactoferrin, Biochem. Cell Biol. 80 (2002) 75-80 https://doi.org/10.1139/o01-228.

[10] Y.A. Suzuki, V. Lopez, B. Lönnerdal, Mammalian lactoferrin receptors: structure and function, Cell. Mol. Life Sci. 62 (2005) 2560-2575 https://doi.org/10.1007/ s00018-005-5371-1.

[11] A.I. Maneva, L.M. Sirakov, V.V. Manev, Lactoferrin binding to neutrophilic polymorphonuclear leucocytes, Int. J. Biochem. 15 (1983) 981-984 https://doi.org/10. 1016/0020-711X(83)90179-9.

[12] H.S. Birgens, H. Karle, N.E. Hansen, K.L. Ostergaard, Lactoferrin receptors in normal and leukaemic human blood cells, Scand. J. Haematol. 33 (1984) 275-280 https://doi.org/10.1111/j.1600-0609.1984.tb02228.x.
[13] L.A. Boxer, R.A. Haak, H.H. Yang, J.B. Wolach, J.A. Whitcomb, C.J. Butterick, R.L. Baehner, Membrane-bound lactoferrin alters the surface properties of polymorphonuclear leukocytes, J. Clin. Investig. 70 (1982) 1049-1057 https://doi.org/ 10.1172/jci110692.

[14] L.V. Deriy, J. Chor, L.L. Thomas, Surface expression of lactoferrin by resting neutrophils, Biochem. Biophys. Res. Commun. 275 (2000) 241-246 https://doi.org/10. 1006/bbrc. 2000.3284.

[15] M. Gahr, C.P. Speer, B. Damerau, G. Sawatzki, Influence of lactoferrin on the function of human polymorphonuclear leukocytes and monocytes, J. Leukoc. Biol. 49 (1991) 427-433 https://doi.org/10.1002/jlb.49.5.427.

[16] N. Francis, S.H. Wong, P. Hampson, K. Wang, S.P. Young, H.P. Deigner, M. Salmon, D. Scheel-Toellner, L.M. Lord, Lactoferrin inhibits neutrophil apoptosis via blockade of proximal apoptotic signaling events, Biochim. Biophys. Acta 1813 (2011) 1822-1826 https://doi.org/10.1016/j.bbamcr.2011.07.004.

[17] K. Okubo, M. Kamiya, Y. Urano, H. Nishi, J.M. Herter, T. Mayadas, D. Hirohama, K. Suzuki, H. Kawakami, M. Tanaka, M. Kurosawa, S. Kagaya, K. Hishikawa, M. Nangaku, T. Fujita, M. Hayashi, J. Hirahashi, Lactoferrin suppresses neutrophil extracellular traps release in inflammation, EBioMedicine 10 (2016) 204-215 https://doi.org/10.1016/j.ebiom.2016.07.012.

[18] H. Miyauchi, S. Hashimoto, M. Nakajima, I. Shinoda, Y. Fukuwatari, H. Hayasawa, Bovine lactoferrin stimulates the phagocytic activity of human neutrophils: identification of its active domain, Cell. Immunol. 187 (1998) 34-37 https://doi.org/10. 1006/cimm.1997.1246.

[19] R. Oseas, H.-H. Yang, R.L. Baehner, L.A. Boxer, Lactoferrin: a promoter of polymorphonuclear leukocyte adhesiveness, Blood 57 (1981) 939-945.

[20] V.S. Lukashevich, A.I. Budzevich, I.V. Semak, V.N. Kuznetsova, E.V. Malyushkova, A.E. Pyzh, S.A. Novakovskaya, J.A. Rudnichenko, N.A. Popkov, O.A. Ivashkevich, I.V. Zalutsky, Production of recombinant human lactoferrin from the milk of goatproducers and its physiological effects, Dokl. Natsionalnoi Akad. Nauk. Belarusi 60 (2016) 72-81 (in Russian).

[21] I. Semak, A. Budzevich, E. Maliushkova, V. Kuzniatsova, N. Popkov, I. Zalutsky, O. Ivashkevich, Development of dairy herd of transgenic goats as biofactory for large-scale production of biologically active recombinant human lactoferrin, Transgenic Res. (2019), https://doi.org/10.1007/s11248-019-00165-y.

[22] A.B. Rachman, R.R.A. Maheswari, M.S. Bachroem, Composition and isolation of lactoferrin from colostrum and milk of various goat breeds, Procedia Food Sci 3 (2015) 200-210 https://doi.org/10.1016/j.profoo.2015.01.022.

[23] N.A. Podoplelova, A.N. Sveshnikova, Y.N. Kotova, A. Eckly, N. Receveur, D. Yu Nechipurenko, S.I. Obydennyi, I.I. Kireev, C. Gacher, F.I. Ataullakhanov, P.H. Mangin, M.A. Panteleev, Blood coagulation factors bound to procoagulant platelets are concentrated in their cap structures to promote clotting, Blood 128 (2016) 1745-1755 https://doi.org/10.1182/blood-2016-02-696898.

[24] I.V. Gorudko, D.V. Grigorieva, A.V. Sokolov, E.V. Shamova, V.A. Kostevich, I.V. Kudryavtsev, E.D. Syromiatnikova, V.B. Vasilyev, S.N. Cherenkevich, O.M. Panasenko, Neutrophil activation in response to monomeric myeloperoxidase, Biochem. Cell Biol. 96 (2018) 592-601 https://doi.org/10.1139/bcb-2017-0290.

[25] I.V. Gorudko, A.V. Mukhortova, B. Caraher, M. Ren, S.N. Cherenkevich, G.M. Kelly, A.V. Timoshenko, Lectin-induced activation of plasma membrane NADPH oxidase in cholesterol-depleted human neutrophils, Arch. Biochem. Biophys. 516 (2011) 173-181 https://doi.org/10.1016/j.abb.2011.10.013.

[26] A.V. Timoshenko, K. Kayser, H.J. Gabius, Lectin-triggered superoxide $/ \mathrm{H}_{2} \mathrm{O}_{2}$ and granule enzyme release from cells, Methods Mol. Med. 9 (1998) 441-451 https:// doi.org/10.1385/0-89603-396-1:441.

[27] I.V. Gorudko, A.V. Timoshenko, Effect of signaling inhibitors on the release of lysozyme from human neutrophils activated by Sambucus nigra agglutinin, Biochemistry (Mosc.) 65 (2000) 940-945.

[28] A.V. Timoshenko, K. Kayser, P. Drings, S. André, X. Dong, H. Kaltner, M. Schneller, H.J. Gabius, Carbohydrate-binding proteins (plant/human lectins and autoantibodies from human serum) as mediators of release of lysozyme, elastase, and myeloperoxidase from human neutrophils, Res. Exp. Med. (Berl.) 195 (1995) 153-162 https://doi.org/10.1007/BF02576784.

[29] I.V. Gorudko, O.S. Tcherkalina, A.V. Sokolov, M.O. Pulina, E.T. Zakharova, V.B. Vasilyev, S.N. Cherenkevich, O.M. Panasenko, New approaches to the measurement of the concentration and peroxidase activity of myeloperoxidase in human blood plasma, Russ. J. Bioorganic Chem. 35 (2009) 566-575 https://doi. org/10.1134/S1068162009050057.

[30] A.V. Timoshenko, I.V. Gorudko, O.V. Maslakova, S. André, I. Kuwabara, F.T. Liu, H. Kaltner, H.J. Gabius, Analysis of selected blood and immune cell responses to carbohydrate-dependent, surface binding of proto- and chimera-type galectins, Mol. Cell. Biochem. 250 (2003) 139-149 https://doi.org/10.1023/A:1024952727159.

[31] G. Grynkiewicz, M. Poenie, R.Y. Tsoen, A new generation of $\mathrm{Ca}^{2+}$ indicators with greatly improved fluorescence properties, J. Biol. Chem. 260 (1985) 3440-3450.

[32] A.V. Timoshenko, S.N. Cherenkevich, Induced aggregation of cells, Ukrainian Biochem. J. 63 (1991) 3-14.

[33] I.V. Gorudko, I.V. Buko, S.N. Cherenkevich, L.Z. Polonetsky, A.V. Timoshenko, Lectin-induced aggregates of blood cells from patients with acute coronary syndromes, Arch. Med. Res. 39 (2008) 674-681 https://doi.org/10.1016/j.arcmed. 2008.06.002.

[34] A.V. Timoshenko, I.V. Gorudko, S.N. Cherenkevich, H.J. Gabius, Differential potency of two crosslinking plant lectins to induce formation of haptenic-sugar-resistant aggregates of rat thymocytes by post-binding signaling, FEBS Lett. 449 (1999) 75-78 https://doi.org/10.1016/S0014-5793(99)00329-4.

[35] I. Harfi, F. Corazza, S. D'Hondt, E. Sariban, Differential calcium regulation of proinflammatory activities in human neutrophils exposed to the neuropeptide pituitary adenylate cyclase-activating protein, J. Immunol. 175 (2005) 4091-4102 https://doi.org/10.4049/jimmunol.175.6.4091. 
[36] C.C. Silliman, D.J. Elzi, D.R. Ambruso, R.J. Musters, C. Hamiel, R.J. Harbeck, A.J. Paterson, A.J. Bjornsen, T.H. Wyman, M. Kelher, K.M. England, N. McLaughlinMalaxecheberria, C.C. Barnett, J. Aiboshi, A. Bannerjee, Lysophosphatidylcholines prime the NADPH oxidase and stimulate multiple neutrophil functions through changes in cytosolic calcium, J. Leukoc. Biol. 73 (2003) 511-524 https://doi.org/ 10.1189/jlb.0402179.

[37] G. Wanten, S. van Emst-De Vries, T. Naber, P. Willems, Nutritional lipid emulsions modulate cellular signaling and activation of human neutrophils, J. Lipid Res. 42 (2001) 428-436.

[38] P. Sabała, M. Czarny, J.P. Woronczak, J. Barańska, Thapsigargin: potent inhibitor of $\mathrm{Ca}^{2+}$ transport ATP-ases of endoplasmic and sarcoplasmic reticulum, Acta Biochim. Pol. 40 (1993) 309-319.

[39] L. Fedrizzi, D. Lim, E. Carafoli, Calcium and signal transduction, Biochem. Mol. Biol. Educ. 36 (2008) 175-180 https://doi.org/10.1002/bmb.20187.

[40] M.J. Berridge, P. Lipp, M.D. Bootman, The versatility and universality of calcium signalling, Nat. Rev. Mol. Cell Biol. 1 (2000) 11-21 https://doi.org/10.1038/ 35036035.

[41] E. Carafoli, Calcium signaling: a tale for all seasons, Proc. Natl. Acad. Sci. U.S.A. 99 (2002) 1115-1122 https://doi.org/10.1073/pnas.032427999.

[42] M.J. Berridge, M.D. Bootman, H.L. Roderick, Calcium signalling: dynamics, homeostasis and remodelling, Nat. Rev. Mol. Cell Biol. 4 (2003) 517-529 https:// doi.org/10.1038/nrm1155.

[43] S. Bréchard, E.J. Tschirhard, Regulation of superoxide production in neutrophils: role of calcium influx, J. Leukoc. Biol. 84 (2008) 1223-1237 https://doi.org/10. 1189/jlb.0807553.

[44] P. Lacy, G. Eitzen, Control of granule exocytosis in neutrophils, Front. Biosci. 13 (2008) 5559-5570 https://doi.org/10.2741/3099.

[45] P. Nunes, N. Demaurex, The role of calcium signaling in phagocytosis, J. Leukoc. Biol. 88 (2010) 57-68 https://doi.org/10.1189/jlb.0110028.

[46] P.K. Hepter, The cytoskeleton and its regulation by calcium and protons, Plant Physiol. 170 (2016) 3-22 https://doi.org/10.1104/pp.15.01506.

[47] J. Bennett, A. Weeds, Calcium and the cytoskeleton, Br. Med. Bull. 42 (1986) 385-390 https://doi.org/10.1093/oxfordjournals.bmb.a072156.

[48] N.R. Jog, M.J. Rane, G. Lominadze, G.C. Luerman, R.A. Ward, K.R. McLeish, The actin cytoskeleton regulates exocytosis of all neutrophil granule subsets, Am. J. Physiol. Cell Physiol. 292 (2007) 1690-1700 https://doi.org/10.1152/ajpcell. 00384.2006.

[49] L. Zhu, V. Castranova, P. He, fMLP-stimulated neutrophils increase endothelial $\left[\mathrm{Ca}^{2+}\right]_{\mathrm{i}}$ and microvessel permeability in the absence of adhesion: role of reactive oxygen species, Am. J. Physiol. Heart Circ. Physiol. 288 (2005) 1331-1338 https:// doi.org/10.1152/ajpheart.00802.2004.

[50] L. Bei, T. Hu, Z.M. Qian, X. Shen, Extracellular $\mathrm{Ca}^{2+}$ regulates the respiratory burst of human neutrophils, Biochim. Biophys. Acta 1404 (1998) 475-483 https://doi. org/10.1016/s0167-4889(98)00081-0.

[51] J.K. French, N.P. Hurst, P.D. Zalewski, L. Valente, I.J. Forbes, Calcium ionophore
A23187 enhances human neutrophil superoxide release, stimulated by phorbol dibutyrate, by converting phorbol ester receptors from a low- to high-affinity state, FEBS (Fed. Eur. Biochem. Soc.) Lett. 212 (1987) 242-246 https://doi.org/10.1016/ 0014-5793(87)81353-4.

[52] S.B. Majee, G.R. Biswas, Exploring plant lectins in diagnosis, prophylaxis and therapy, J. Med. Plants Res. 7 (2013) 3444-3451 https://doi.org/10.5897/ JMPR2013.5289.

[53] E.P. Schmidt, W.L. Lee, R.L. Zemans, C. Yamashita, G.P. Downey, On, around, and through: neutrophil-endothelial interactions in innate immunity, Physiology 26 (2011) 334-347 https://doi.org/10.1152/physiol.00011.2011.

[54] D.N. Granger, E. Senchenkova, Inflammation and the Microcirculation, Morgan\& Claypool Life Sciences, San Rafael (CA), 2010https://doi.org/10.4199/ C00013ED1V01Y201006ISP008.

[55] A.V. Timoshenko, I.V. Gorudko, H.J. Gabius, Lectins from medicinal plants: bioeffectors with diverse activities, Recent Adv. Phytochem. 44 (2014) 43-56 https:// doi.org/10.1007/978-3-319-04045-5 3.

[56] I.V. Gorudko, A.V. Vakhrusheva, A.V. Mukhortova, S.N. Cherenkevich, A.V. Timoshenko, V.I. Sergienko, O.M. Panasenko, The priming effect of halogenated phospholipids on the functional responses of human neutrophils, Biochem. Moscow Suppl. Ser. A 4 (2010) 262-271 https://doi.org/10.1134/ S1990747810030037.

[57] F. Giansanti, G. Panella, L. Leboffe, G. Antonini, Lactoferrin from milk: nutraceutical and pharmacological properties, Pharmaceuticals 9 (2016) E61 https:// doi.org/10.3390/ph9040061.

[58] I.A. García-Montoya, T.S. Cendón, S. Arévalo-Gallegos, Q. Rascón-Cruz, Lactoferrin a multiple bioactive protein: an overview, Biochim. Biophys. Acta 1820 (2012) 226-236 https://doi.org/10.1016/j.bbagen.2011.06.018.

[59] C. Conesa, M. Calvo, L. Sánchez, Recombinant human lactoferrin: a valuable protein for pharmaceutical products and functional foods, Biotechnol. Adv. 28 (2010) 831-838 https://doi.org/10.1016/j.biotechadv.2010.07.002.

[60] J.L. Eyles, A.W. Roberts, D. Metcalf, I.P. Wicks, Granulocyte colony-stimulating factor and neutrophils-forgotten mediators of inflammatory disease, Nat. Clin. Pract. Rheumatol. 2 (2006) 500-510 https://doi.org/10.1038/ncprheum0291.

[61] H.L. Wright, R.J. Moots, R.C. Bucknall, S.W. Edwards, Neutrophil function in in flammation and inflammatory diseases, Rheumatology 46 (2010) 1618-1631 https://doi.org/10.1093/rheumatology/keq045.

[62] A.V. Timoshenko, S.N. Cherenkevich, A.B. Samal, Role of active oxygen species in concanavalin A-induced agglutination of lymphocytes, Vestn. Bel. Uni. Ser. 2 Khim. Biol. Geo. Geogr. 3 (1986) 47-50 (in Russian).

[63] E.B. Lynam, S. Rogelj, B.S. Edwards, L.A. Sklar, Enhanced aggregation of human neutrophils by $\mathrm{MnCl} 2$ or DTT differentiates the roles of L-selectin and beta 2-integrins, J. Leukoc. Biol. 60 (1996) 356-364 https://doi.org/10.1002/jlb.60.3.356.

[64] K. Futosi, S. Fodor, A. Mócsai, Neutrophil cell surface receptors and their intracellular signal transduction pathways, Int. Immunopharmacol. 17 (2013) 638-650 https://doi.org/10.1016/j.intimp.2013.06.034. 